\title{
ACCEPTANCE (QABÛL) AND TAKING POSSESSION (QABD) OF HIBAH UNDER ISLAMIC LAW AND THE DECISION OF THE SYARIAH COURTS IN MALAYSIA ${ }^{1}$
}

\author{
Badruddin Hj Ibrahim²
}

\begin{abstract}
One of the important components in the creation of contract in Islamic law, apart from the contracting parties ('âqidân) and subject matter of contract (mahal al-'aqd), is formation (ṣ̂ghah). It consists of two essential elements i.e. offer (îjâb) and acceptance (qabûl). The absence of formation will render the contract invalid and imperfect. Nevertheless, in the case of hibah as it is a kind of contract of charity (tabarru'), the issue arises as to whether the element of acceptance is required in order to constitute a valid hibah. Added to this is the issue of whether hibah is completed and ownership of property transferred to the recipient as is the case with other types of contract when all of the above three components of
\end{abstract}

1 This paper was originally presented at International Seminar on Comparative Law 2008, organized by Islamic Science University of Malaysia, Putra Jaya, Malaysia, 18-19 November 2008. It was funded by Research Management Centre, International Islamic University Malaysia.

Assistant Professor, Ahmad Ibrahim Kulliyyah of Laws, International Islamic University Malaysia. 
contract and their requirements are fulfilled. This study examines issues relating to these two important matters of hibah, since disputes among parties in the Syariah Courts of Malaysia mostly involve these. The examination focuses on the positions of Muslim jurists of the four well-known schools of law, i.e. Shâfi 'î, Hanafî, Mâlikî and Hanbalî, on the issues. In addition, as the law of hibah for Muslims in Malaysia is mostly uncodified, the study also examines the law that has been applied by various Syariah Courts in Malaysia regarding these issues, especially whether their decisions are solely based on the law according to the school of Shâfi î. This is in order to find out an acceptable set of rules that could govern the creation of a valid and perfect hibah.

\section{INTRODUCTION}

Islamic law (sharî' $a h$ ) is a body of rules pertaining to the conduct of a person which is embodied in the texts of the Qur'an and the Sunnah, and derived by Muslim jurists through the process of ijtihäd by means of established principles and methodologies found in the Qur'ann and the Sunnah. ${ }^{3}$ It is a revealed law which principally consists of two main divisions: devotions ('ibādah) and civil matters (' $\bar{a} d a h / m u$ 'ämalah). The purpose of the former is to organize the relationship between man and his Creator. Meanwhile the latter pertains to the relationship between man and man, which includes all types of rules relating to family, property, transactions, crime and punishment etc. ${ }^{4}$

In Malaysia, the application of Islamic law is very limited. It is a state matter, and is principally confined to personal and family matters. The Syariah Court of each state in Malaysia, and the Syariah Court of the Federal Territories are given the power to administer Islamic law for

\footnotetext{
3 See Hassan, Husayn Hāmid, al-Madkhal li Dirāsat al-Fiqh al-Islāmī, $2^{\text {nd }}$ Edition, Maktabat al-Mutanabbī, Cairo, 1979, 7-10.

4 Ibid., 15-21.
} 
Muslims in their respective jurisdictions. Hibah is one of the matters that fall exclusively under the jurisdiction of the Syariah Court. For example, section 61 (3) of Administration of the Religion of Islam (State of Selangor) Enactment $2003^{5}$ provides:

"The Syariah High Court shall-

(a) in its criminal jurisdiction, try...

(b) in its civil jurisdiction, hear and determine all action and proceeding if all the parties to the actions or proceedings are Muslim and the actions and proceedings related to-

(i) betrothal, marriage, ruju'...

(ii) $\quad \ldots$

(iii) $\quad \ldots$

(iv) $\quad \ldots$

(v) ...gifts inter vivos,...”

To date, there is no specific provision on hibah under Islamic law in Malaysia. However, many cases have been brought to the Syariah Court for decision. This study will focus on issues relating to acceptance and taking possession of subject matter of hibah under Islamic law in general and the law as applicable in Malaysia.

\section{MEANING OF HIBAH AND HOW IT DIFFERS FROM OTHER TYPES OF DISPOSITION}

Hibah is a type of disposition of property that takes effect during a person's lifetime i.e. an inter vivos disposition. ${ }^{6}$ It is a voluntary disposition where a person may give his property to whomever he wishes, be it a relative or a stranger. ${ }^{7}$ However, hibah to relatives is

Enactment No. 1 of 2003.

Al-Anșārī, al-Qāọī Abī Zakariyyā Yahyya, Asnāa al-Matālib sharh Raw ḍ al-Ṭālib, Dār al-Kutub al- 'Tlmiyyah, Beirut, 1422H/2001, Vol. 8, 565; Ibn Qudāmah, Abī Muḥammad 'Abd Allah ibn Ahmad ibn Muhammad, alMughnī, Dār al-Kutub al- 'Ilmiyyah, Beirut, 1414H/1994, Vol. 5, 387. Al-Ghamrāwī, Muhammad Zuhrī, Anwār al-Masālik sharh 'Umdah al-Sālik wa 'Uddah al-Nāsik, Dār al-Fikr, Beirut, n.d, 261. 
preferred, ${ }^{8}$ as the Qur' an clearly lays down that voluntary disposition of property firstly begins with the relatives. ${ }^{9}$ It states:

“...To spend of your substance, out of love for Him, for your kin, for orphans, for the needy, for the wayfarer, for those who ask...”10

Hibah is a contract of transferring ownership of property that falls under the charitable category like endowment (waqf), bequest (wassiyyah), loan for use (i'ärah) and alms, which is based on giving (or helping) by one person to another without any exchange. ${ }^{11}$ It is unanimously agreed that the legal ruling $(\mathrm{hukm})$ on making hibah is that it is commendable. ${ }^{12}$ Its objective in general is to strengthen the relationship among family members as well as members of the society. In addition, it inculcates in a person a sense of love, brotherhood and friendship, or in other words, a sense of responsibility toward his family member or his fellow human being. ${ }^{13}$ Islam emphatically encourages Muslims to help each other in promoting and doing good deeds as the Qur'ān clearly states, "Help you one another in righteousness and piety..." 14

Al-' Imrānī, Abī al-Ḥusayn Yahyya ibn Abī al-Khayr ibn Sālim, al-Bayān fī Madhhab al-Shāfi ‘̄ , Dār al-Minhāj, n.pp, 1421H/2000,Vol. 8, 108; Ibn Qudāmah, Abī Muḥammad 'Abd Allah ibn Ahmmad ibn Muhammad, alKāfī fī Fiqh al-Imām Aḥmad ibn Hanbal, al-Maktab al-Islāmī, Beirut, 1408H/1998, 520.

9 Al-'Imrānī, Vol. 8, 108.

10 Al-Qur'ān, al-Baqarah (2):177.

Shalabī, Muhammad Mușțafā, al-Madkhal fī Ta 'rīf bi al-Fiqh al-Islāmī wa Qawā'id al-Milkiyyah wa al-'Uqūd fïhi, Dār al-Nahḍah al'Arabiyyah, Beirut, 1405H/1985, 567.

12 Al-Zayla 'ī, Fakhr al-Dīn 'Uthmān ibn 'Alī, Tabyīn al-Haqā'iq Sharh Kanz al-Daqà ’iq, Dār al-Kutub al-'Ilmiyyah, Beirut, 1420H/2000, Vol. 6, 48; al-Nafrāwī, Aḥmad ibn Ghanīm ibn Sālim ibn Mahannā, alFawākih al-Dawānī 'ala Risālah Ibn Abì Zayd al-Qayrawānī, Dār alKutub al-'Ilmiyyah, Beirut, n.d., Vol. 2, 253; al-'Imrānī, Vol. 8, 107; Ibn Qudāmah, al-Mughnī, Vol. 5, 387.

13 Al-Sarakhsī, Abī Bakr Muḥammad ibn Aḥmad ibn Abī Sahal, alMabsūt, Dār al-Kutub al-'Ilmiyyah, Beirut, 1999, Vol. 11, 56; al-Zayla 'ī, Vol. 6, 48.

14 Al-Qur'ān, al-Mā'idah (5):2. 
Generally, hibah differs from other types of dispositions of similar nature like alms (sadaqah) and presents (hadiyyah). Sadaqah is basically giving property either to a needy or wealthy person where a giver expects a reward in life after death. ${ }^{15}$ Meanwhile (hadiyyah) is giving a property as a mark of honour, endearment, ${ }^{16}$ a reward or bonus to a recipient ${ }^{17}$ and basically deals with a movable property. ${ }^{18}$ Majority of the Shäfi ' 1 jurists are of the view that these two types of disposition do not necessarily require the element of offer and acceptance and can take place by mere give and take ${ }^{19}$ which definitely differs from hibah.

\section{THE ESSENTIAL ELEMENTS OF HIBAH}

Creation of hibah, like the creation of any other types of contract, is deemed valid if all of its essential elements and requirements are fulfilled. Nevertheless, Muslim jurists have different opinions regarding the important elements of hibah. The Mālikîs, Shâfi î̀s and Ḥanbalîs view that the contracting parties (i.e. donor and donee), subject matter of hibah (i.e. property given), and formation (i.e. offer and acceptance) are the important elements of hibah. ${ }^{20}$ Without these three elements,

Al-Marghīnānī, Burhān al-Dīn Abī al-Ḥasan ibn Abī Bakr, al-Hidāyah Sharh Bidāyat al-Mubtad̄̄, n.d., Dār Iḥyā’ al-Turāth al-'Arābī, Beirut, Vol. 3, 229; al-Ghamrāwī, Muhammad al-Zuhrī, al-Sirāj al-Wahhāj, Dār al-Fikr, n.pp, n.d., 307; al-Bahūtī, Manșūr ibn Yūnus ibn Idrīs, Kashshāf al-Qinā' 'an Matn al-Iqnā's, Dār al-Fikr, Beirut, 1402H/1982, Vol. 4, 299. Al-Husnī, Taqīy al-Dīn Abī Bakr ibn Muhammad, Kifāyat al-Akhyār fī Hall Ghāyat al-Ikhtiṣār, Dār al-Khayr, Beirut, 1414H/1994, Vol. 1, 307; al-Bahutī, Vol. 4, 299.

$17 \quad$ Al-Bahūtī, Vol. 4, 299.

18 Al-Nawawī, Abī Zakariyyā Yahya ibn Sharaf, Rawdat al-Tālibīn, Dār al-Kutub al-'Ilmiyyah, Beirut, 1421H/2001, Vol. 4, 437; Yūsof, al-Shaykh Mar'ī al-Hanbalī, Ghāyat al-Muntahā fì al-Jam' Bayn al-Iqnā' wa alMuntahā, al-Mu’assasah al-Sa 'diyyah, al-Riyāḍ, n.d., Vol. 2, 318. Al-Nawawī, Vol. 4, 428; al-Anșārī, Vol. 5, 568.

Al-Dardīr, Abī al-Barakāt Aḥmad ibn Muhammad ibn Aḥmad, al-Sharh al-Saghīr 'alā Aqrab al-Masālik ìlā Madhhab al-Imām Mālik, Wizārat al- 'Adl wa al-Shu'ūn al-Islāmiyyah wa al-Awqāf, United Arab Emirate, 1410H/1989, Vol. 4, 141; al-Anșārī, Vol. 5, 567 \& 574; al-Lablayhī, Șālih ibn Ibrāhīm, al-Salsabīl fì Ma'rifat al-Dalīl, Maktabat Nizār Muștafa al-Bāz, al-Riyāḍ, 1417H/1996, Vol. 3, 230. 
hibah is invalid. This view, in principle, is also the view of the Syariah Courts in Malaysia. For instance, in Salmiah binti Che Hat v Zakaria bin Hashim, ${ }^{21}$ the Syariah Lower Court of Bukit Mertajam Pulau Pinang stated that:

"Hibah has three elements: parties to a contract of hibah i.e. donor and donee; contract ('aqd) i.e. offer and acceptance; and subject matter of hibah."22

On the other hand, the Hanafî jurists confine the element of hibah to the formation only. ${ }^{23}$ The difference of opinions regarding the issue, however, is merely theoretical. This is because if there is formation, it is inevitable that there shall be contracting parties as well as property given. Since offer and acceptance originate from contracting parties (i.e. donor and donee), the offer by the donor and the acceptance by the donee shall have legal effect on the subject matter of hibah. In this regard, Hāmid Hassan in his discussion on the essential elements of contract in general under Islamic law asserts that:

"The difference of opinion between the majority of Muslim jurists and Hanafī scholars ${ }^{24}$ is merely theoretical and it does not result in any legal effect in practice.”25

The above discussion shows that the Muslim jurists are unanimous that the formation (sîghah) constitutes one of the important elements in the creation of a valid hibah. The absence of formation will make hibah invalid.

\footnotetext{
$21 \quad$ (2001) $14 \mathrm{JH} 79$.

$22 \quad$ (2001) $14 \mathrm{JH} 82$.

23 Al-Kāsānī, 'Ala’ al-Dīn Abī Bakr ibn Mas'ūd, Badā'i ‘ al-Sanā’i ‘ fi Tartīb al-Sharā'i ', Dār al-Fikr, Beirut, 1417H/1996,Vol. 6, 174.

24 That is regarding the essential elements of contract.

25 Hassan, al-Madkhal li Dirāsat al-Fiqh al-Islāmī, 241.
} 


\section{ACCEPTANCE OF HIBAH}

The question that arises is whether the validity of hibah requires both elements of formation, i.e. offer by donor and acceptance by donee. Would it be sufficient if the element of offer exists, while the element of acceptance is missing? In other words, whether hibah can be created with the intention of one party only, i.e. donor, or does it require the intentions of both the donor and the donee.

The majority of Muslim jurists (i.e. the Mālikīs, Shāfi 'iss and Hanbaliss) hold the view that the validity of hibah is subject to the existence of both elements of formation, i.e. offer by donor and acceptance by donee. ${ }^{26}$ The argument for this view is that hibah is a type of transaction consisting of transfer of ownership from one person to another, and therefore it requires both elements of offer and acceptance similar to other contracts of alienation of property, such as a contract of sale. ${ }^{27}$ This view is supported by some Hanafī jurists where the chief proponent is Zufar, ${ }^{28}$ the disciple of Abū Haniffah, followed by other jurists like alQudūrīi, ${ }^{29}$ al-Marghīnānin ${ }^{30}$ and al-Mawșalīi, ${ }^{31}$ all of whom opine that the validity of hibah depends on both elements of formation. ${ }^{32}$ As hibah is

'Abd al-Wahhāb al-Baghdādī, al-Qaḍi Abū Muhammad, al-Ishrāf 'ala Nakt Masā’il al-Khilāf, Dār Ibn Hazm, Beirut, 1420H/1999, Vol. 2, 673; al-Shīrāzī, Abī Ishāà Ibrāhīm ibn 'Alī ibn Yūsof al-Fayrūz Abādī, alMuhadhdhab fī Fiqh al-Imām al-Shāfi ' $\imath$, Dār Iḥyā' al-Turāth al-'Arabī, Beirut Lebanon, 1414H/1994, Vol. 1, 583; Ibn Mufliḥ, Abī Ishạā Burhān al-Dīn Ibrāhīm ibn Muhammad, al-Mubdi ' Sharḥ al-Muqni`, Dār alKutub al-'Ilmiyyah, Beirut, 1418H/1997, Vol. 5, 192.

Al-Shīrāzī, Vol. 1, 583; Ibn al-Muqri’, Sharaf al-Dīn Ismā īl ibn Abī Bakr ibn 'Abd Allah, Ikhlaṣ al-Nāwī fì Irshād al-Ghāwì ilā Masālik alHāwì̄, Dār al-Kutub al-'Ilmīyyah, Beirut Lebanon, 1424H/2004, Vol. 2, 236.

28 He is al-Imām Zufar ibn al-Huzayl ibn Qays al-' Anbarī al-Bașarī died in $158 \mathrm{H} / 775$.

29 Died in $428 \mathrm{H} / 1037$.

$30 \quad$ Died in $593 \mathrm{H} / 1179$.

31 Died in 683H/1285.

32 See al-Kāsānī, Vol. 6, 174; al-Qudūrī, Abī al-Hasan Aḥmad ibn Ja'far, Mukhtașar al-Qudūrī fī al-Fiqh al-Hanafī, Dār al-Kutub al-' Ilmiyyah, Beirut, 1418H/1997, 124; al-Marghīnānī, Vol. 3, 222; al-Mawșalī, 'Abd Allah ibn Maḥmūd ibn Mawdūd, al-Ikhtiyār li Ta 'īl al-Mukhtār, Dār al-Kutub al-'Ilmiyyah, Beirut, 1419H/1998, Vol. 3, 54. 
a contract, it is similar to any other type of contract which requires both elements of formation for its validity. ${ }^{33}$ This means that the acceptance by the donee is necessary in order to constitute a valid hibah and consequently, if there is only an offer by the donor without an acceptance by the donee, hibah is invalid and it does not therefore exist.

On the other hand, some Hanafi jurists hold the view that the important element of hibah is only the offer by the donor, and the acceptance by the donee is not necessary. ${ }^{34}$ This means that the validity of hibah depends merely on the offer by the donor. Thus according to this view hibah can be created with the intention of one party only. The basis of this view is that hibah is a type of charitable contract and therefore, it is validly created with the intention of the donor only as is the case with bequest (wasiyyah). ${ }^{35}$ On this basis, they argue that if a person swears that he will not make a hibah to a particular person, and later makes a hibah in favour of that person, it is considered as a breach of his oath even though there is no acceptance from that person. ${ }^{36}$ Nevertheless, al- 'Ayni ${ }^{37}$ and Qāọī Zādah Afandīi ${ }^{38}$ contend that the element of acceptance is meant to establish ownership of the donee and its position is the same as that of taking possession. ${ }^{39}$ In this regard, some Hanafī jurists have raised doubt relating to the non-requirement of acceptance in the creation of a valid hibah. This is because according to the Hanafī school, acceptance of hibah need not necessarily be verbal, as acceptance may also take place by conduct. ${ }^{40}$ Consequently, Ibn 'Ābidīn

\footnotetext{
33 Al-Zayla ī, Vol. 6, 49.

34 Al-Kāsānī, Vol. 6, 174; Qāọī Zādah Afandī Sham al-Dīn Aḥmad ibn Qūdir, Natā’ij al-Afkār fī Kashf al-Rumūz wa al-Asrār, Dār al-Fikr, Beirut, n.d., Vol. 9, 19-20.

35 Qādịi Zādah Afandī, Vol. 9, 19. Al-Maydānī, 'Abd al-Ghanī al-Ghanīmī, al-Lubāb fī Sharh al-Kitāb, al-Maktabah al-'Ilmiyyah, Beirut, 1413H/1993, Vol. 1, 171.

37 Died in $885 \mathrm{H} / 1480$.

38 Died in $988 \mathrm{H} / 1580$.

39 Qāḍi Zādah Afandī, Vol. 9, 19-20; Badr al-Dīn al- 'Aynī, Mahmūd ibn Aḥmad ibn Mūsa, al-Banāyah Sharh al-Hidāyah, Dār al-Kutub al'Ilmiyyah, Beirut, 1420H/2000, Vol. 10, 160.

40 See Ibn 'Ābidīn, Muhammad Amīn ibn 'Umar, Radd al-Mukhtār 'ala al-Durr al-Mukhtār, Dār Iḥyā’ al-Turāth al- 'Arabī, Beirut, 1419/1998, Vol. 8, 426.
} 
assumes that those who opine that hibah does not require acceptance, refer to acceptance by word. ${ }^{41}$ It does not mean that hibah does not require the element of acceptance at all. Based on this, he concludes that the two views regarding the requirement of acceptance in the creation of hibah could be reconciled."

The above discussion indicates that the element of acceptance is necessary in the creation of a valid hibah according to the Hanafi jurists. However, the mode of acceptance need not necessarily be verbal, as it can also be by conduct. This view is further supported by Majallah al-Ahkām al- 'Adliyyah ${ }^{43}$ where article 837 clearly states that, "Hibah is concluded by offer and acceptance...." Thus the position of the Hanafi jurists on the issue of the acceptance of hibah is the same as the majority of jurists.

Therefore, the consent of both parties is necessary in the creation of a valid hibah, since mutual consent is the basis of the creation of a valid contract under Islamic law. The Qur'ān clearly states:

"O you who believe, devour not your property among yourselves by unlawful means except that it be trading by your mutual consent." ${ }^{44}$

The position of Syariah Courts in Malaysia on the issue of acceptance of hibah is also in a state of flux. Some Syariah Courts seem to agree with the view of the majority of Muslim jurists. In Salmiah binti Che Hat $v$ Zakaria bin Hassan, ${ }^{45}$ the Syariah Lower Court of Bukit Mertajam Pulau Pinang held, among others, that hibah of a plot of land in the district of Seberang Tengah by the plaintiff and the defendant's adopted father to the defendant was not valid, since there was no acceptance by the defendant, ${ }^{46}$ even though the defendant had taken the land and built a house on such land. The court asserted that the evidence provided by the defendant did not not show that the defendant had

\begin{tabular}{ll}
\hline 41 & Ibid. \\
42 & Ibid. \\
& Majallah al-Ahkkām al- 'Adliyyah is the Ottoman Civil Code which is \\
& basically based on the Hanafi school of law. \\
& Al-Qur'ān, al-Nisā'(4):29. \\
44 & (2001) 14 JH 79. \\
45 & (2001) 14 JH 83-84.
\end{tabular}


pronounced acceptance of hibah verbally. In addition, there was no documentary evidence to support the matter. ${ }^{47}$

On the other hand, some of the Syariah Courts seem to have applied the view of some Hanafi jurists. There were cases where hibah was held to be valid even though there was no acceptance. In Poolimahee Rajeswary@ Fatimah binti Babav Meah binti Hassan, ${ }^{48}$ the Syariah High Court of Federal Territories held that a piece of land with a house bearing the address Lot 6C, Kampung Sri Petaling, Pantai Dalam Kuala Lumpur, was a hibah of the late Baba bin Othman to his adopted daughter, Fatimah binti Baba, the plaintiff. The said properties were later taken by the government for the purpose of construction of a highway and all compensation related to the properties was to be delivered to the plaintiff. The court also nullified the inheritance certificate issued by the Syariah Court Kuala Lumpur bearing No 079/2001 dated 16 August 2001 which excluded the plaintiff from entitlement to the property left by Baba. In this case, based on evidence that had been provided, there was only the offer by the late Baba without acceptance of hibah by the plaintiff either by word, in writing or by action. However, the court clearly held that all elements of hibah existed. ${ }^{49}$

Similar is the case of validation of hibah to Norizan Bt. Mansor, ${ }^{50}$ the plaintiff. The plaintiff was an adopted daughter of the late Jamaliah bt. Burhan, who owned a half portion of the land of Lot 231, while another half was owned by her sister. During her lifetime she declared in writing her intention to give her portion of the land to the plaintiff. After the said land was sold, the late Jamaliah did not have opportunity to collect the ten percent of advance payment by herself, instead she entrusted the plaintiff to collect the said payment. After the death of Jamaliah, the plaintiff did not collect the rest of the payment, since she was uncertain regarding the status of the money, whether it was considered as a part of the estate of the late Jamaliah or the latter's hibah to her. The Syariah High Court of Pulau Pinang held that the selling price of the land was a hibah of the late Jamaliah to the plaintiff. In this case there was no clear acceptance of hibah by the plaintiff but

\begin{tabular}{ll}
\hline 47 & (2001) 14 JH 85. \\
48 & (2005) 19 JH 164. \\
49 & (2005) 19 JH 166-169. \\
50 & (2004) 17 JH 69.
\end{tabular}


the court was of the view that the hibah has been concluded. The court observed as follows:

"In this matter the donor has given the hibah property to the plaintiff and the plaintiff has also received ten percent of the selling price of the said property as an advance payment. In the opinion of the Court, the element of hibah has been fulfilled since such hibah has taken place when both donor and donee are still alive. There is the circumstantial evidence or the expression by word which was mentioned by the witness that such hibah will be given to the plaintiff as a sympathetic gesture towards her since she still has a small child." 51

In the case of Eshah bt Abdullah and five others $v$ Aminah bt Abdul Razak, Minah bt. Awang, Kalsom Binti Mohamad, ${ }^{52}$ the Syariah High Court of Terengganu clearly adopted the view of some Hanafī jurists. The court stated that:

"According to Islamic law hibah is completed in the contractual session of hibah even though without stating "I accepted." 53

Thus in this case, it was held that 2/12 of the land at Lot 3467, Mukim Bukit Besar, Kuala Terengganu, that was owned by late Muhamad bin Abdullah, consisting of three shop lots, was hibah from the late Muhamad in favour of Aminah bt Abdul Razak, the first defendant, and Noraini Hayati binti Mohamad Yusof and Zaini binti Mohamad (i.e. one shop lot for each one of them). This is regardless of the fact that the said hibah was not accepted by the first defendant and the other two recipients. The plaintiffs were not satisfied with the decision of the court and appealed to the Syariah Appellate Court. ${ }^{54}$

\begin{tabular}{ll}
\hline 51 & (2004) 17 JH 71-72. \\
52 & (2003) 16 JH 51. \\
53 & (2003) 16 JH 59. \\
54 & See n. 117.
\end{tabular}




\section{MODE OF ACCEPTANCE}

Acceptance is an important element of formation in the creation of a valid hibah according to the majority of Muslim jurists. They are unanimous that the acceptance can be done verbally by expressing the words "I accept" or "I agree." 55 This is so because verbal expression is the original form of communicating intention and manifestation of the will. $^{56}$

With respect to acceptance by conduct or by taking possession of the subject matter of hibah, the majority of the jurists (i.e. the Hanafīs, Mālikīs, and Hanbalīs) consider such form of acceptance valid ${ }^{57}$ since it is the manifestation of consent. Some of the Shäfi ' $\overline{1}$ jurists, particularly the later jurists, seem to agree with the majority view. This is because they adopt the same position as the majority jurists that hibah can be created by conduct (al-ta $a \bar{a} t \bar{\imath}){ }^{58}$ An example of acceptance by conduct is where a person says to another "I give this property to you" and then that person takes such property without saying "I accept." Such hibah is considered valid. ${ }^{59}$ Taking the property given is tantamount to acceptance. This rule has been laid down in Majallah al-Ahkām al'Adliyyah where article 841 clearly states:

55 Ibn Nujaym, Zayn al-Dīn ibn Ibrāhīm ibn Muhammad, al-Bahr al-Rā'iq Sharḥ Kanz Daqā’iq, Dār al-Kutub al-'Ilmiyyah, Beirut, 1418/1997, Vol. 7, 485; al-Hatțāb, Abī 'Abd Allah Muḥammad ibn Muḥammad, Mawāhib al-Jalīl li Sharh Mukhtaṣar Khalīl, Dār al-Kutub al'Ilmiyyah, Beirut, 1416H/1995, Vol. 8, 10; al-Anșārī, Vol. 5, 567-568; Ibrāhīm al-Maqdisī, al- 'Uddah fī Sharh al- 'Umdah, Mu’assasat alRisālah, Beirut, 1421H/2001, Vol. 1, 431. Hassan, 242.

Ibn Nujaym, Vol. 7, 485; al-Hatțāb, Vol. 8, 10; Ibn al-Najjār, Taqiy al-Dīn Muhạmmad ibn Aḥmad al-Futūḥ̄, Muntaha al-Irādāt, $2^{\text {nd }}$ Edition, 'Ālam al-Kutub, Beirut, 1416H/1996, Vol. 1, 437.

Al-Haytamī, Shihāb al-Dīn Abī al-'Abbās Aḥmad Ibn Muḥammad, Tuḥfat al-Muḥtāj bi Sharḥ al-Minhāj, Dār al-Kutub al-' Ilmiyyah, Beirut, 1421H/2001, Vol. 2, 521; al-Malībārī, Zayn al-Dīn ibn 'Abd al- 'Azīz, Fath al-Mu 'in bi Sharh Qurrat al- 'Ayn bi Muhimmāt al-Dīn, Dār alKutub al-'Ilmiyyah, Beirut, 1418H/1998, 137.

Al-Zayla'`i, Vol. 6, 49-50. 
“Taking possession of hibah is like acceptance in a sale. Based on this, hibah is completed when the donee takes possession of property given in a meeting even without saying, "I have accepted" or "I have accepted the gift" at a time when the donor said, "I have given this property to you."

Some Syariah Courts in Malaysia follow the view of the majority of Muslim jurists. In the case of Harun bin Muda and others $v$ Mandak bin Mamat and others, ${ }^{60}$ the Syariah High Court of Terengganu was of the view that the acceptance of hibah is not necessarily by word but may also be by conduct, for instance, by developing the property given or by making use of such property. ${ }^{61}$ Similarly, in the case of Eshah binti Abdullah and five others $v$ Che Aminah binti Abdul Razak and two others $^{62}$ as discussed above, the Syariah Appellate Court considered the acceptance by conduct favourably. The court ruled that all the three recipients of hibah in this case i.e. Che Aminah, Noraini and Zaini received the rental money of the said hibah property and this can be considered as circumstantial evidence of acceptance. ${ }^{63}$ Thus the court maintained the decision of the Syariah High Court with a minor amendment that the hibah claimed by Che Aminah, the first respondent, is valid. Meanwhile Noraini and Zaini were to claim their own portion. ${ }^{64}$ The question that may be raised here is whether the acceptance in these two cases is considered valid since it did not take place in the contractual session (majlis al- 'aqd).

\section{TIME OF ACCEPTANCE}

Regarding the time of acceptance, the question is whether the acceptance shall be made immediately after the offer has been made, without any interruption, or whether it is not necessary to be done

\begin{tabular}{ll}
\hline 60 & $(1999) 13 \mathrm{JH}$ 63. \\
61 & $(1999) 13 \mathrm{JH}$ 73-74. \\
62 & $(2004) 18 \mathrm{JH}$ 47. \\
63 & $(2004) 18 \mathrm{JH} 60-61$. \\
64 & $(2004) 18 \mathrm{JH} 48$.
\end{tabular}


immediately. Muslim jurists (i.e. Ḥanafīs, Mālikīs, Shafi īs and Ḥanbalīs) seem to agree on the issue that the acceptance has to take place in a single contractual session without any interruption. ${ }^{65}$ However, the Shafi' is emphasise that the acceptance shall be made immediately after the offer ${ }^{66}$ or it shall be with reasonable continuity without any interruption. ${ }^{67}$ Meanwhile the Hanbalīs hold that it need not be at once but may take place during the contractual session, without any interruption. ${ }^{68}$ The Mālikīs also are of the same view as the Hanbalīs where the donee is allowed to deliberate before acceptance. ${ }^{69}$

Thus it is unanimously agreed that the acceptance of hibah by word or by deed shall take place in the contractual session. Where the acceptance takes place after the contractual session, hibah is invalid. In the application to validate the hibah of Ismail Siak to his daughter Wan Ismariza Wan Ismail ${ }^{70}$ the Syariah High Court of Negeri Sembilan held that hibah of one plot of land by the former to the latter complied with Islamic law as all essential elements of hibah were fulfilled and offer and acceptance having been concluded verbally in the contractual session. ${ }^{71}$ The Syariah High Court of Pahang held a position similar to the Syariah High Court of Negeri Sembilan in the case pertaining to the validation of hibah of Siti Noor Aseera bt. Awang. ${ }^{72}$ It was held that the hibah of agricultural land of 1.03 hectares, one lot of land with house, and money amounting to RM 77,914.99 deposited with ASB, by the late Awang bin Ismail to his daughter Siti Noor Aseera was valid according to Islamic law. ${ }^{73}$ In this case, Siti clearly pronounced the acceptance of hibah by words in the contractual session i.e. immediately after her late father made the offer. ${ }^{74}$

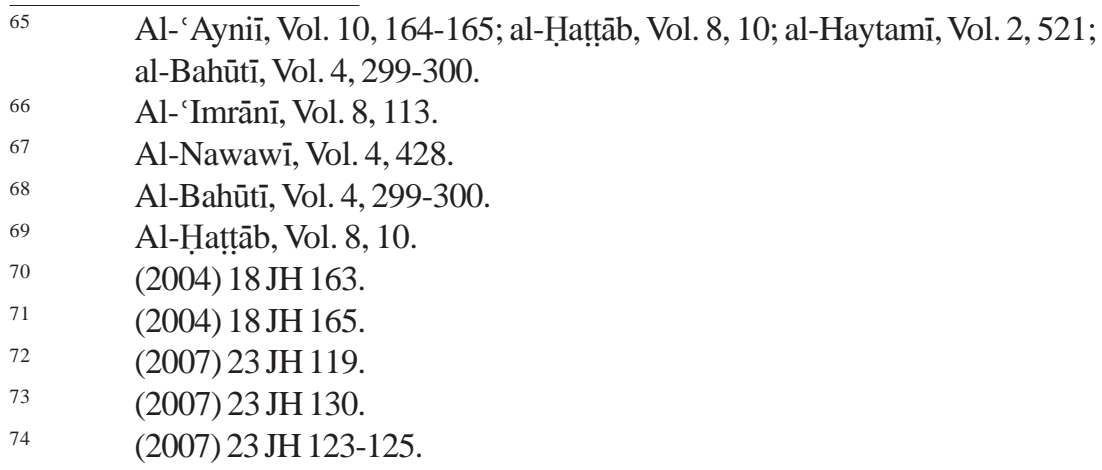


On the other hand, the acceptance of hibah by conduct in the case of Harun bin Muda and others $v$ Mandak bin Mamat and others $^{75}$ and the acceptance of rental money from hibah property in case of Eshah binti Abdullah \& Five Others v Che Aminah binti Abdul Razak \& Two Others ${ }^{76}$ shall not be considered as valid acceptance according to the view of the four Muslim schools of law since the acceptance by conduct in these two cases did not take place within the contractual session of hibah.

\section{TAKING POSSESSION OF SUBJECT MATTER OF HIBAH}

The contract of hibah is not only concerned with the issue of validity but also with the issue of completion. The question is when does it become complete and binding or in other words, when is the ownership of the subject matter of hibah transferred to the donee? The Muslim jurists again differ on the issue. The Mālikî jurists are of the view that hibah is considered valid and complete by mere contract even without taking possession. ${ }^{77}$ This is also the view attributed to Imām Ahmad where the subject of hibah is a type that cannot be weighed and measured. ${ }^{78}$ The main authority for this view is the Qur'ān which enjoins every Muslim to fulfill all types of contracts. It clearly states to the effect, "O ye who believe! Fulfill (all) obligations."79 The view of the Mālikīs and Imām Ahmad is further strengthened by the Sunnah of the Prophet (peace be upon him) where it is reported that the Prophet (peace be upon him) said, "One who takes back his hibah is like a dog which takes back its vomit.”"80 According to Qāẹī 'Abd al-Wahhāb ${ }^{81}$ of the Mālikī school, the Sunnah does not differentiae whether the question of taking

\footnotetext{
$75 \quad$ (1999) $13 \mathrm{JH} 73-74$.

$76 \quad$ (2004) $18 \mathrm{JH} 47$.

77 'Abd al-Wahhāb al-Baghdādī, al-Qaḍi Abū Muhammad, al-Ma'ūnah, Dār al-Fikr, Beirut, 1419H/1999, Vol. 3, 1607; al-Khurashī, Muhammad Ibn 'Abd Allah ibn 'Alī, Hāshiyat al-Khurashī 'ala Mukhtașar Saydī Khalīl, Dār al-Kutub al-'Ilmiyyah, Beirut, 1417H/1997, Vol. 7, 411. Ibn Qudāmah, al-Mughnī, Vol. 5, 389.

Al-Qur'ān, al-Mā'idah (5): 1.

It is reported by Bukhārī and Muslim.

Died in 422H/1031.
} 
back the subject matter of hibah is before or after taking delivery. ${ }^{82}$ The Mālikī and Hanbalī jurists further argue that because hibah is a charitable disposition, it does not require taking possession, similar to the case of a bequest. ${ }^{83}$ In addition, Qāḍi 'Abd al-Wahhāb contends that hibah is a type of contract, so it is similar to contracts that do not require taking possession for completion. ${ }^{84}$ Similarly, Ibn Muflih ${ }^{85}$ of the Hanbalī school asserts that hibah is a type of binding contract, so it is not subject to taking possession, similar to a contract of sale. ${ }^{86}$ Thus according to the Mālikīs, when hibah is concluded, a donor is obliged to deliver the subject matter of hibah to the donee and in case the donor refuses to give delivery, he can be compelled by the Court to do so. ${ }^{87}$

On the other hand, the Hanafī, Shäfi ' $\overline{1}$, and majority of the Hanbali jurists hold that hibah will not be complete without the taking possession of its subject matter. ${ }^{88}$ The exception is where the subject matter is already in the possession of the donee. ${ }^{89}$ This means that hibah will not become binding and ownership of the subject matter will not be transferred to the donee without taking possession. The basis of this view is the consensus (ijm $\left.\bar{a}^{c}\right)$ of the Companions.

"From Ibn Shihâb from 'Urwah ibn al-Zubayr that 'A' 'ishah, the wife of the Prophet, may Allah bless him and grant him peace, said, "Abû Bakr al-Șiddīq gave me palm trees whose produce was twenty awsaq from his property at al-Ghâbah. When he was dying, he said, By Allah, little daughter, there is no one other than you I

82 'Abd al-Wahhāb, al-Ma'ūnah, Vol. 3, 1608.

$83 \quad$ Ibid.; Ibn Muflih, Vol. 5, 193.

84 'Abd al-Wahhāb, al-Ma'ūnah, Vol. 3, 1608.

85 Died in 884H/1479.

86 Ibn Muflih, Vol. 5, 193.

$87 \quad$ Al-Khurashī, Vol. 7, 411.

Al-Zayla 'î, Vol. 6, 49; al- 'Imrānī, Vol. 8, 114; al-Mirdāwī, 'Alā’ al-Dīn Abī al-Ḥasan 'Alī ibn Sulaymān, al-Inșāffì Ma'rifat al-Rājị̣ min alKhilāf 'ala Madhhab al-Imām al-Mubajjal Aḥmad ibn Hanbal, Dār Ihyā' al-Turāth al-'Arabī, Beirut, 1376H/1957, Vol. 7, 119-120. Muḥammad, al-Sharh al-Mumti' 'ala Zād al-Mustaqni' fī Ikhtișār alMuqni ', al-Kitāb al-`Ālamī, Beirut, 1426H/2005, Vol. 5, 106. 
would prefer to be wealthy after I die. It would bring me the most pain if I were to see you in a state of poverty before my death. I gave you palm trees whose produce is twenty awsaq. Had you cut them and taken possession of them, they would have been yours, but today they are the property of the heirs, and they are your two brothers and two sisters, so divide it according to the Book of Allah....”90

The same view is also reported from, 'Umar, 'Uthmān, Ibn 'Umar, Ibn 'Abbās, 'Ā'ishah, Mu'ādh and Anas. ${ }^{91}$ In this respect, al- 'Imrānī, ${ }^{92}$ the Shāfi ' 1 jurist, asserts that,

"No one differed with those companions, therefore, it indicates that there was a consensus of opinion."93

Al-Sarakhsīi ${ }^{94}$ of the Hanafī jurists argues that if the ownership of the subject matter of hibah is established for the donee before taking possession, it is obligatory on the donor to deliver it to the donee. This is clearly contrary to the nature of hibah itself, which is a voluntary disposition. ${ }^{95}$ In addition, al-Mawșali asserts that the nature of a contract of donation is weak, while the ownership of property that is established for the donor is strong, therefore it will not come to an end due to a weak reason ${ }^{96}$ i.e. by mere contract.

Regarding the authority of the Qur'ann that is relied upon by the Mālikīs, al-Māwardīi, ${ }^{97}$ the Shāfi ' $\overline{1}$ jurist, argues that the verse which commands every Muslim to fulfill all obligations is applicable to binding contracts. ${ }^{98}$ With regard to the Sunnah, it refers to the situation where

\footnotetext{
90 It is reported by Imâm Mâlik.

91 See al-' Imrānī, Vol. 8, 115.

92 Died in 558H/1163.

93 See al-'Imrānī, Vol. 8, 115.

94 Died in 490H/1097.

$95 \quad$ Al-Sarakhsī, Vol. 11, 56.

96 Al-Mawșalī, 54-55.

97 Died in 450H/1058.

98 Al-Māwardī, Abī al-Hasan 'Alī ibn Muhammad ibn Habīb, al-HāwīalKabīr, Dār al-Kutub al-'Ilmiyyah, Beirut, 1419H/1999, Vol. 7, 536.
} 
taking possession has taken place. ${ }^{99}$ Concerning the analogy of hibah with bequest, it is unacceptable, as the subjects of analogy are different. In this regard, al-Marghīnānī contends that,
"Hibah is different from bequest since the ownership of property in bequest is established in the legatee after the death of the legator. Consequently it cannot be envisaged on the part of the legator to deliver the subject matter of bequest because he has no legal capacity to do so since he has died.” ${ }^{100}$

Regarding the analogy of hibah with sale, it is also between two different issues. In this respect, al-Baghawī ${ }^{101}$ a Shāfi ' $\overline{1}$ jurist, argues that:

\begin{abstract}
"Sale is a contract of exchange which is strong in nature, ${ }^{102}$ so it does not require the taking of possession to establish ownership. Meanwhile hibah is a charitable disposition which is weak in nature, therefore it requires the taking of possession." 103
\end{abstract}

The above discussion shows that there is no clear evidence either from the Qur'an or the Sunnah regarding the issue of completion of hibah whether it is completed by mere contract or with taking possession. But viewed from the practice of the Companions, which reflected their understanding on the issue, it is evident that hibah becomes binding not by mere contract but with taking possession. This suggests that the view of the majority of Muslim jurists on the issue is more preferable. The position of the Mālikī jurists on the issue of transferring ownership of the subject matter of hibah to the donee does not really indicate that hibah is completed by mere contract. For instance, in the case of a donee who

\footnotetext{
$99 \quad$ Ibid.

100 Al-Marghīnānī, Vol. 3, 222; See also al-' Aynī, Vol. 10, 162-163.

101 Died in $516 \mathrm{H} / 1122$.

102 That is in term of its binding. The contract of sale is binding by mere contract.

103 Al-Baghawī, Abî Muḥammad al-Ḥusayn ibn Mas'ūd ibn Muhammad, al-Tahdhīb fī al-Fiqh al-Shāfi 'ì, Dār al-Kutub al-'Ilmiyyah, Beirut, 1418H/1997, Vol. 4, 527.
} 
delays taking possession of the subject matter of hibah till the property of a donor is encompassed by debt, they are of the opinion that such hibah is void. This can happen both before as well as after the hibah is created. ${ }^{104}$ In addition, they are also of the view that hibah which has been created in favour of one person, can also be made in favour of another person. In this regard, they are of the opinion that if the second donee takes possession of the subject matter of hibah before the first donee, the ownership of hibah is established in the second donee. ${ }^{105}$ They argue that by taking possession, the position of the second donee is stronger than the first donee, since the first one had neglected in taking possession. ${ }^{106}$ Thus the position of the Mālikī jurists on this point suggests that the ownership of the subject matter of hibah will not be established in the donee without taking possession. If the ownership is established in the donee by mere contract, why does a hibah which has been created in favour of someone become void when the property of the donor is encompassed by his debt, and why does a hibah which has been created in favour of someone allowed to be made to another person?

The mode of taking possession varies according to the nature of the subject matter of hibah. In the case of movable property, it shall be by taking delivery ${ }^{107}$ i.e. by taking the whole of it. ${ }^{108}$ With respect to immovable property it shall be by occupation of the premises when it is vacated $^{109}$ or by taking receipt of keys. ${ }^{110}$

The Syariah Courts in Malaysia in principle agree with the view of the majority of Muslim jurists that hibah is not completed except with taking possession of its subject matter. However, they have provided different interpretations regarding the meaning of taking possession. In the case on the validation of hibah of Ismail bin Siak to Wan Ismariza

$104 \quad$ Al-Khurashî, Vol. 7, 411-412; al-Zarqânî, 'Abd al-Bāqī Ibn Yūsof Ibn Aḥmad, Sharh al-Zarqānī 'ala Mukhtașar Saydī Khalīl, Dār al-Kutub al-'Ilmiyyah, Beirut, 1422H/2002, Vol. 7, 176.

105 Al-Khurashî, Vol. 7, 412; al-Zarqânî, Vol. 7, 176.

106 Al-Khurashî, Vol. 7, 412.

107 Al-Baghawī, Vol. 4, 527; al-Maydānī, Vol. 1, 171; Yūsof, al-Shaykh Mar' ī, Dalìl al-Țālib li Nayl al-Mațālib, $2^{\text {nd }}$ Edition, Mu'assasat al-Kutub alThaqāfiyyah, Beirut, 1991H/1411, 173.

$108 \quad$ Al-Nawawī, Vol. 4, 438.

109 Al-Maydānī, Vol. 1, 171; al-Baghawī, Vol. 4, 527; Yūsof, 173.

$110 \quad$ Al-Maydānī, Vol. 1, 171. 
Bt Wan Ismail, ${ }^{111}$ the Syariah High Court of Negeri Sembilan held that the taking possession of the subject matter of hibah in this case occurred when the land tax was paid by the donee. ${ }^{112}$ In the case on the validation of Hibah of Norizan Bt. Mansor, ${ }^{113}$ taking ten percent as advance payment of land is considered as taking possession of subject matter of hibah. In this respect the Syariah High Court of Pulau Pinang held:

"In this case, the applicant has taken ten percent of the
selling price of the land. In the opinion of the court, it is
one of the significant elements i.e. the subject matter of
hibah has been taken by the recipient of the hibah (the
donee)."114

The above decision made by the Court was presumably based on the premise that if the donor (i.e Jamaliah) was still alive she would have asked Norizah to collect the rest of the selling price. But the question that can be raised here is whether Norizah has collected the advance payment as recipient of the hibah or was just representing the late donor since it was not clearly mentioned. It was only stated that Norizah was entrusted with such collection.

In Poolimahee Rajeswary @ Fatimah binti Babav Meah binti Hassan, ${ }^{115}$ the court held that the occupation of the subject matter of hibah is considered as taking possession. In this case, as discussed above, the donor, before his death, had the intention to transfer the land with the house to the plaintiff but he could not do so due to certain reasons. In addition, he asked the plaintiff not to leave the house if anything happens to him. In this regard, the court was of the opinion that the taking of possession had taken place since the plaintiff had already resided in the house. ${ }^{116}$ In the case of Eshah bt Abdullah and five others $v$ Aminah bt Abdul Razak, Minah bt. Awang, Kalsom Binti Mohamad, ${ }^{117}$ the Syariah Appellate Court of Terengganu considered the acceptance of

\begin{tabular}{ll}
\hline 111 & (2004) 18 JH 163. \\
112 & (2004) 18 JH 165. \\
113 & (2003) 17 JH 69. \\
114 & (2003) 17 JH 72. \\
115 & (2005) 19 JH 164. \\
116 & (2005) 19 JH 170. \\
117 & (2004) 18 JH 47.
\end{tabular}


rent of the premises which was the subject matter of hibah as circumstantial evidence of taking possession. ${ }^{118}$ In this case, however, the donor had not fully delivered the subject matter of hibah to the recipient as he was still paying tax for the premises and responsible for its maintenance. ${ }^{119}$ In addition, he sometimes collected the rent of the premises himself and later forwarded it to the recipient. ${ }^{120}$

\section{PERMISSION OF DONOR IN TAKING POSSESSION}

The majority of Muslim jurists agree that taking possession of the subject matter of hibah is subject to the permission of the donor if it takes place after the contractual session. ${ }^{121}$ Nevertheless, they differ when it takes place in the contractual session.

According to Hanafī jurists, taking of possession in the contractual session without the permission of the donor is valid. ${ }^{122}$ The reason is that the offer made by the donor in creating the hibah is tantamount to an implied indication of permission for taking possession. ${ }^{123}$ This is because the Hanafī school considers taking possession of the subject matter in the contractual session in the case of hibah to be similar to acceptance in the case of a sale contract. As taking possession in the case of sale contract not requiring permission, the position should be the same with regard to hibah. ${ }^{124}$ However, they are of the view that if the donee is prohibited from taking possession, it is invalid to take possession without the donor's permission even in the contractual session since there is an express indication for not doing so. An express indication is stronger than an implied one. ${ }^{125}$

\footnotetext{
$118 \quad$ (2004) 18 JH 60-61.

$119 \quad$ (2004) $18 \mathrm{JH} 52$.

$120 \quad$ (2003) 16 JH 59.

121 Al-Marghīnānī, Vol. 3, 222; al-Nawawî, Vol. 4, 438; Ibn Qudāmah, alMughnī, Vol. 5, 388.

122 Al-Marghīnānī, Vol. 3, 222; al-Zayla 'ī, Vol. 6, 50.

123 Al-Zayla'ī, Vol. 6, 50; al-Maydânī, Vol. 1, 171.

124 Al-Ḥaddādī, Abī Bakr ibn 'Alī, al-Jawharah al-Nayyirah, Mir Muḥammad Kutub Khānah, Karachi, n.d., Vol. 1, 419.

125 Al-'Aynī, Vol. 10, 164; Dāmād Afandī, Vol. 3, 492.
} 
On the other hand, the Shāfi 'îs and Hanbalīs view that taking possession of subject matter of hibah shall be with the permission of the donor even though in the contractual session. ${ }^{126}$ In a case where the donee takes possession of the subject matter of hibah without the permission of the donor, the ownership of the subject matter of hibah will not be transferred to the donee. ${ }^{127}$ This is because the transfer of ownership of the subject matter of hibah is subject to taking possession and therefore it is not permissible without the permission of the donor as the owner. ${ }^{128}$ In addition, Ibn Qudāmah, ${ }^{129}$ a Hanbali jurist, argues that taking possession without permission in the contractual session is the same as taking possession after the meeting, and the situation is also the same when the donee is forbidden from taking possession. This is so, because the donor owes no duty to deliver the hibah, and therefore the delivery is not valid without his permission. ${ }^{130}$

In this issue, it seems that the view of the Hanafīs is more acceptable, as the taking of possession occurs in a meeting of contract and in the presence of the donor. Moreover, there is no indication, of displeasure that prevents the donee from doing so, which implies that permission has been given.

\section{THE DEATH OF DONOR OR DONEE BEFORE TAKING POSSESSION}

It is established that the completion of hibah is subject to taking possession of the subject matter. A question may arise as to whether hibah will be void upon the death of either party, donor or donee, before taking possession of the subject matter. According to Hanafī jurists, hibah becomes void if the donor or the donee dies before taking possession of the subject matter. ${ }^{131}$ Since the subject matter of hibah is not yet transferred to the donee before his taking possession, hibah is not binding.

\footnotetext{
$\overline{126} \quad$ Al-Nawawî, Vol. 4, 438; Ibn Qudāmah, al-Mughnī, Vol. 5, 388.

127 Al-Nawawî, Vol. 4, 438; Ibn Qudāmah, al-Mughnī, Vol. 5, 388.

128 Al-Huṣnī, Vol. 1, 309.

129 Died in 620H/1223.

130 Ibn Qudāmah, al-Mughnī, Vol. 5, 388.

131 Ibn 'Ābidīn, Vol. 8, 439; al-Haddādī, Vol. 1, 419.
} 
Consequently, with the death of the donor, his property will be transferred to his legal heirs. ${ }^{132}$ And in the event of the donee's death, his legal heir shall not inherit the subject matter of hibah since the donee has not yet owned the property. ${ }^{133}$

The preferred view of the Shäfi ' $\overline{1}$ jurists is the opposite of the Hanafī position. According to them, hibah will not be void if either party dies before taking possession, since hibah is a contract leading to binding obligations similar to a contract of sale with conditional option. ${ }^{134}$ In this situation, legal heirs of either party will take the latter's place. Thus in the event of the donor's death, his legal heir will stand in his place. It depends on his legal heir whether to deliver the subject matter of hibah to the donee or not to deliver it. ${ }^{135}$ In the case of the donee passing away, his legal heir will take his place and shall take possession of the subject matter if there is a delivery. ${ }^{136}$

Although the Mālikī jurists are of the opinion that hibah is completed without taking possession, in the case of the donor's death, their position is the same as that of the Hanafīs. ${ }^{137}$ This is where the donee does not make any effort to take possession of the hibah before the death of the donor or where the donor refuses to give delivery of the subject matter; otherwise, hibah will not be void. ${ }^{138}$ Nevertheless, in the case of the donee's death, the position of the Mālikīs is the same as that of the Shäfi 'îs. Thus, the donee's legal heir will stand in the donee's place in claiming delivery. ${ }^{139}$ The preferred view of the Hanbali jurists is contrary to the Mālikī position. In the event of the donor's death, they are of the same position as the Shāfí 'iss, and in the death of the donee,

\footnotetext{
132 Ibn 'Ābidīn, Vol. 8, 439.

133 Al-Haddādī, Vol.1, 419.

$134 \quad$ Al-Baghawī, Vol. 4, 528; al-Nawawī, Vol. 4, 437.

135 Ibid.

$136 \quad$ Ibid.

137 Al-Nafrāwī, Vol. 2, 254; al-Sharnūbī, 'Abd al-Majīd ibn Ibrāhīm, Taqrīb al-Ma'ān̄̄ ' ala Matn al-Risālah, Dār al-Kutub al-'Ilmiyyah, Beirut, 1418H/1998, 174.

138 Al-Sharnūbī, 174.

Abī Qāsim, 'Ubayd Allah ibn al-Ḥusayn ibn al-Hasan, al-Tafrī‘ , Dār alGharb al-Islāmī, Beirut, 1408H/1987, Vol. 2, 313; al-Qarāfī, Shihāb alDīn Abī al-'Abbās Aḥmad ibn Idrīs, al-Dhakhīrah fī Furū' alMālikiyyah, Dār al-Kutub al-'Ilmiyyah, Beirut, 1423H/2001, Vol. 5, 357.
} 
they are with the Hanafis. ${ }^{140}$ This is because in the death of the donor, they view that hibah is a contract which is leading to binding obligations ${ }^{141}$ and therefore it shall not be void. Nevertheless, in the death of the donee, they hold the view that taking possession of the hibah is similar to acceptance. Thus hibah will be void similar to a contract of sale, when a party to the contract dies before acceptance. ${ }^{142}$

It seems that in the case of the donor's death, the view of Hanafīs and those who are with them is preferable. This is so because hibah does not become binding until taking possession, and the ownership of the subject matter of hibah is not yet transferred to the donee. Thus with the death of the donor, his property will be transferred to his legal heirs. With regard to the death of the donee, the view of the Shäfi ' 1 jurists is more acceptable, as the donor is still alive, and the completion of hibah is subject to delivery of the subject matter by him. Thus it depends on him either to deliver the subject matter of hibah or not to deliver it.

\section{CONCLUSION}

The discussion shows that the Muslim jurists have differences of opinion on the validity and completion of hibah, relating to the issues of acceptance and taking possession of the subject matter of hibah. Consequently, Syariah Courts in Malaysia are also varied in their decision, particularly regarding the issue of acceptance of hibah. This reveals that the Syariah Courts in Malaysia do not rely only on the law based on

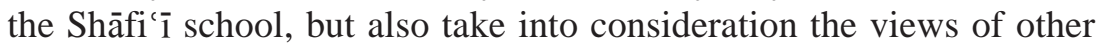
schools. It is interesting to note that the Muslim jurists who are of the view that the validity of hibah depends on the existence of the element of offer, nevertheless, emphasise that the completion of hibah depends on taking possession of the subject matter. Meanwhile those who consider that the completion of hibah is achieved without taking possession of the subject matter, however, emphasise that the validity of hibah is subject to the existence of both the elements of offer and acceptance. Therefore, any decision which considers that the validity and completion of hibah

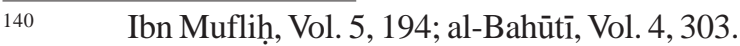

141 Al-Bahūtị, Vol. 4, 303.

142 Ibid.
} 
depends on the element of offer by the donor alone is not in line with what has been laid down by the Muslim Jurists of the four schools of law.

To conclude, it is submitted that the validity of hibah depends on the existence of the intention of both parties (i.e. offer by donor and acceptance by donee) since it is a type of contract. It is not only the intention of the donor that is required but also the intention of the donee, in order to show that the latter is willing to accept the hibah. The acceptance shall be by word or by conduct which is concluded in the contractual session similar to other types of contract of the same nature. In addition, it is also submitted that the completion of hibah is not by mere contract alone but also by taking possession of the subject matter. This is because hibah, although a type of contract involving transferring ownership of property from one to another, is a voluntary disposition, which differs from obligatory dispositions. Therefore, there should be a strong indication on the part of the donor showing his firm intent to dispose of his property, namely by delivering the subject matter of hibah. Taking possession of the subject matter of hibah shall be with the permission of the donor if it takes place after the contractual session, since the latter is still its owner. Hibah will not be void on the death of the donee before taking possession, since the donor is still alive. It will then depend on him whether to carry out his wish or not. On the contrary, in the event of the donor's death, hibah will definitely be void since the subject matter has not yet been transferred to the donee, resulting in it being transferred to the donor's legal heirs as inheritance. 